\title{
Business Ethics and Artificial Intelligence: Towards the Underlying Concept of Man
}

\author{
Dr. Claudius Mandel \\ FOM - Hochschulefür Oekonomie und Management \\ University of Cologne, Professional Center \\ Germany
}

\begin{abstract}
Artificial Intelligence (AI) and its social implications are a key challenge of the contemporary world. This includes ethical and anthropological issues. Dealing with these issues asks for an interdisciplinary discourse - for example with philosophers, economists, and engineering scientists. The most important position among those who advocate AI development is 'trans-humanism'. In the following essay, the motives and arguments of this position and particularly its anthropological concept are analyzed and critically evaluated from a variety of perspectives, including ethics and business economics.
\end{abstract}

Keywords: business ethics, business economics, Artificial Intelligence, transhumanism, concept of man, singularitarianism, technological singularity

\section{Business ethics and Artificial Intelligence}

The reflection of ethical principles in the context of economic action can be traced back in the history of ideas and theory to the unity of ethics, politics and economy by Aristotle. Since the emancipation of economics from late medieval moral philosophy in the 19th century, however, ethics and economics have long been in a disciplinary disproportion - an economic rationality oriented towards efficiency and self-interest versus the question of a good life in the sense of correct interpersonal action. For several decades, however, interest in business ethics has been revived: the increasing destruction of the environment, growing inequality of distribution, and not least tasks in the context of global digitization raise the question of the normative foundations of economic activity. The situation-specific application of ethical principles to new social developments and life situations takes place within the framework of applied ethics. From a technological point of view, the central social development of the present can be summed up by the term Artificial Intelligence, i.e. the automation of intelligent behavior in the context of machine learning. From an ethical perspective, on the one hand it can be asked on a practical level whether and if so on which ethical concepts relevant statements of certain companies active in the field of Artificial Intelligence are based and what purpose they pursue. On this basis, the practical behavior of these relevant actors could then be analyzed and evaluated from an ethical point of view. On the other hand, it is also worth taking a look at a theoretical level that examines the topic of Artificial Intelligence, for example with its anthropological basic assumptions: When dealing with the topic of Artificial Intelligence in the economic context, it seems clear that this object of investigation is interwoven with fundamental anthropological questions. A sketchy discussion of the following questions addressed in this paper can provide a critical view of the anthropological and ethical assumptions in the current debate on Artificial Intelligence:

- Which concept of man expresses the endeavor to perfect artificially intelligent machine behavior?

- Which (psychoanalytical) motives can be responsible for favoring such a concept of man?

- How can this concept of man be critically considered and evaluated from an ethical perspective?

\section{Artificial Intelligence and Transhumanism: Man and Machine}

Transhumanism can be identified as the philosophical line of thought that seeks to expand the limits of human possibilities through the use of technological processes - especially intellectually, but also physically or psychologically. Among the various transhumanist currents, singularitarianism is closely linked to developments in Artificial Intelligence. The representatives of singularitarianism proceed from the assumption that the state of so-called technological singularity will soon occur. This can be understood as a point in time at which machines rapidly improve themselves by means of Artificial Intelligence and thus accelerate technical progress to such an extent that the duration of human life expectancy can be significantly increased or even biological immortality achieved. The most prominent current representative of this way of thinking of transhumanism is Raymond Kurzweil, Director of Engineering at Google: Kurzweil thinks man as an information-processing intelligence that is still bound to a biological shell, but will soon become potentially immortal as an electronic platform (cf. Kurzweil 2006). 
However, interweaving questions of Artificial Intelligence with fundamental anthropological considerations is not new. The German philosopher, cultural anthropologist and psychoanalytical media theorist Dietmar Kamper already drew this connection in the 1980s. He formulated theses that could serve the current discussion on the one hand as a philosophical anthropological foundation for dealing with Artificial Intelligence. On the other hand, these considerations have the potential to serve as a guideline for answering questions about motives for the emergence of transhumanist currents and, building on this, as an orientation aid for the current topic-specific ethical discussion. For these reasons, Kampers' thoughts in this essay - in the sense of a Grounded Theory approach - are to be re-updated in order to make them suitable for connection as a contribution to the current field of discussion on Artificial Intelligence, anthropology and ethics.

Kamper'sopen anthropology possesses its nucleus in the conviction that it cannot answer the question of man conceptually - insofar as this is to be understood as a definitory determination (genus proximum and differentia specifica) to be made once and for all. Rather, Kamper would like to explore central traces of social change. For the author this means the following: "Instead of the border to the animal, the transition to the machine seems to be the problem of contemporary anthropology". (Kamper 1988, p. 82, own translation). Following this basic thesis, Kamper no longer wants to consider man in a definitive demarcation to the animal, but in a hypothetically gliding, transitional scenario that blurs all boundaries: This consideration means a redefinition of man at the interface of the 20th to the $21 \mathrm{st}$ century, which is supposed to do justice to the third industrial revolution, the digitalization and computerization of the world, as the central historical-social developmental step in technical terms: With the formula "deus qua machina" (Kamper 1988a, p. 82, own translation) Kamper describes man already in 1988 as the future constructor of an intellectually intended exposed machine being, which makes itself superfluous in a certain way in the operation of a perfection of artificially intelligent machine behavior.

These remarks by Kampers are, it can be worked out, based on two mutually converging approaches, which finally lead to the special proposal of Kampers for an adequate determination of the contemporary human being. As far as the strategy of demarcation from the animal, which has meanwhile been classified as obsolete, is concerned, these considerations follow Gernot Boehme's explanations in his Anthropologie in pragmatischerHinsicht (anthropology in a pragmatic way) (cf. Kamper 1988, p. 85 f.): Boehme concedes that nowadays a certain calmness has occurred towards animals (cf. Böhme 1985, p. 238), with the consequence that it is no longer important to have to distinguish oneself from it in order to determine oneself. As a reason for this Böhme puts the circumstance into question that mankind in the course of evolutionary history had actually achieved the desired superiority over animals, which makes a theoretical discussion of differences superfluous. In contrast to Kamper, Boehme positions his concept of a sovereign humanbeing who can love, work and integrate events into his own self-understanding as a counterproposal, whereby one of his main sources for this is again identical with that which Kamper conjures up for his reversal of the strategy of deposition from the animal (cf. Kamper 1988, p. 86): Arnold Gehlen's conception of man as a being of defects (Mängelwesen) is mentioned here. In the course of this determination - in reaction to the organic unspecialization of humans - it depends on one's own effort, on substituting and overcoming human insufficiency and weakness, on the design of a world that goes beyond humans. In this respect, a strategy of demarcation from the animal appears to be a secondary problem, almost banal (cf. Gehlen 1963 and 1974).

For Kamper here, feeling committed to the social change of his time, a different approach is now necessary. He wants to read and interpret the transformation of natural deficiencies into artificial strengths as a special case of a worldwide machinization of the human mind. Consequently, it is not mechanics and not electrification, but computerization that provides the model of an inevitable human transgression. (cf. Kamper 1988, p. 86; cf. Kamper 1995, p. 183). It is important for Kamper to note that this consideration exceeds those approaches which attribute to man a striving for organ lengthening by means of technology; here, for example, Freud's understanding of a prosthetic god would have to be taken into account, whereby Gehlen still listens to this approach. Instead, according to the author, it is now a matter of "the tendency, possible by means of feedback circuits, towards the complete automaton, which leaves the horizon of anthropocentric technology and seeks to enable an exteriorization of productive fantasy through the emptying of natural self-reflexivity". (Kamper 1988, p. 86, own translation).Kamper speaks of an "imaginatively gifted, self-reflexive machine" (Kamper 1988, p. 82, own translation), which in future must be at the centre of anthropological considerations.

This described "tendency towards automatic self-reflection" (Kamper 1990a, p. 151, own translation), repeatedly referred to by Kamper as the "transition to transhumanism" (Kamper 1988, p. 90), as the "transhuman expansion" (Kamper 1995, p. 182, own translation), expresses a suggestion that is expressed by the term Artificial Intelligence, which is well known and used today (2019) by a broad public. This means an automation of intelligent behavior, however equipped. Kamper also uses this term, albeit already at a time (beginning in the 1980s) when the discussion about it is largely conducted in expert circles and rarely woven into fundamental anthropological considerations. 
By making aware of the "project of Artificial Intelligence" (Kamper 1988, p. 90, own translation), Kamper does exactly the latter and is thus ahead of his time in this respect: Kamper already thinks of man here in the context of a full automation of the world that is in the meantime, that is to say today, actually emerging, whose efficient productivity reaches undreamt-of heights, although or rather precisely because man - after having initiated this process himself makes himself largely superfluous in certain respects, i.e. takes himself out of the game of increasing productivity with his own hands.

For the new paradigm he has in mind in his confrontation with man, Kamper is looking for a powerful formula that sums up the relationship to be rethought. This is derived from the basic thesis already mentioned: "Instead of the border to the animal, the transition to the machine seems to be the problem of contemporary anthropology". (Kamper 1988, p. 82, own translation). The following short formula then reads "deus qua machina". (Kamper 1988, p. 82, p. 82 and p. 86; cf. Kamper 1990a, p. 151) and thus expresses, according to Kamper, the questionable "hope for an incomparable superiority of the great automaton" (Kamper 1988, p. 90, own translation). Kamper is aware that this formula is not a definitive term - in the sense of a definition of man by means of a generic term and specific difference, but a hypothetical one: "The new that occurs cannot be determined as precisely as the old - this is in the nature of the thing. It still has no fixed contours and is exposed to guessing. Even in the present case it still has a hypothetical character. It derives from a well-founded suspicion." (Kamper 1988, p. 83, own translation) - a suspicion that is understood as fulfilled by the current thought of transhumanism that relies on technological singularity.

\section{Artificial Intelligence and Transhumanism: Psychoanalytical Motives}

"A new foreignness is produced in which technology and technocracy become puzzling figures par excellence. One wonders anew and from the very beginning what anthropological significance the machines have." (Kamper 1990a, p. 151, own translation)

In order to shed light on the motives for the representation of a transhumanist view of the world and the human being, Kampers' psychoanalytical considerations, which he borrowed from Jacques Lacan's system of thought, can be followed up (cf. Lacan 1966, 1973, 1987, 1996). The transhumanist concept of man, with Artificial Intelligence as its motor, can be attributed the significance of a protective shield for the human psyche - because this approach conceals the intolerability par excellence that people associate with their lives at all, their mortality. Singularity thinking thus deletes the psychoanalytically known empty hope of the ego for identity, it deletes awareness of the inevitability of human finiteness, irrevocable human mortality (cf. Kamper 1994, p. 20). Transhumanism, in the variety of singularitarianism, replaces the memory of the lost unity presented in Lacan's mirror stage and the associated fear of death with the promise of immortality: the given imperfect world of human bodies, their frailties, their mortality, is replaced by an access to a (supposedly) perfect, artificial world. In machine format people and things are immortal and thus promise the overcoming of death (cf. Kamper 1995, p. 86): "This seems to me to be the great seduction and also the justification for getting involved in it and thus, if you like, replacing the imperfect given world with an artificial world". (Kamper 1990b, own translation). This self-help strategy finally strikes back from the individual to the social level. The decisive effect is that death is completely excluded in collective discourse. As if it no longer took place, as if it had become superfluous in the meantime, it becomes an unparalleled taboo subject. The idea of being able to explain death as a settled issue also shows itself from a broader perspective to be related to the transhumanist concept of man: Against the background of the findings of a progressive mechanization of the world, the quest for Artificial Intelligence can be understood as the current expression of an ultimate quest for omnipotence. This works towards a displacement of nature as God's creation in favor of the installation of a purely technical world made by man (cf. Kamper 1986c, p. 14): "Substitution of nature by technology is in a certain way the answer, the practical answer of man to provocation, that they themselves are not creators of themselves." (Kamper 1994, p. 14, own translation).

As far as the statements on transhuman expansion in the sense of a mechanization of the mind to overcome the inadequacy of human natural resources are concerned, Kampers' reflections can in part be attributed originality. However, this is not the case with regard to the comparatively more frequently expressed thoughts on the organextending mechanization of the human body. Such considerations can already be found in much more elaborate form in Guenther Anders' writing on the Antiquiertheit des Menschen (antiquated nature of man). Kamper repeatedly refers to this as an input source (cf. Kamper 1988, p. 83; cf. Kamper 1998, p. 110 f.) for the thoughts he himself put forward in the direction mentioned. In Anders' aforementioned work he states that the human being surrounded by cybernetic apparatuses is characterized by a peculiar Promethean shame that arises from the insight that he has become and not been made. Man thus remains in value behind the perfectible, thoroughly calculated impeccability of the technical products of a few researchers (cf. Anders 1956, p. 24). According to Anders, man countered this scandal by attempting assimilation to the apparatus world (cf. Anders 1956, p. $30 \mathrm{ff}$.). Thus actually an even earlier consideration from Sigmund Freud has been caught up: 
In his later work Unbehagen in der Kultur, not only the profane dream is interpreted as the fulfilment of man's most secret desires, but also, with the advancing development of civilization, in particular the mechanization of the earth qua human hand. In this Freud sees the approach to a divine ideal: "Now man has come very close to achieving this ideal, has almost become a God himself. (Freud 1948, p. 450, own translation) - that is the conclusion of human cultural development according to Freud, which is further aggravated by Anders' thesis understanding the machine as man`s God (cf. Anders 1956, p. 36). These two sequences are reflected again in the following words of Kampers: "Man, in order to emphasize himself, thinks the thoughts of God before the creation of the world and makes of it the machine. (Kamper 1996, p. 141, own translation).

\section{Artificial Intelligence and Transhumanism: Ethical Reflection}

This approach to man as constructor of an exposed machine being, not only physically, but also mentally, expressed in the formula "deus qua machina" (Kamper 1988, p. 82, own translation), does not happen value-free. For Kamper it is clear that a human being acting in this way can no longer be a human being (cf. Kamper 1988, p. 82). He classifies the attempt as presumptuous that wants to create a global artefact that replaces the old creation (cf. Kamper 1990b). Francis Fukuyama, when accusing transhumanism of relying on technological developments without sufficiently taking into account the ethical aspects associated with them, puts the same punch. Fukuyama therefore even comes to the conclusion that transhumanism could critically undermine the progressive ideals of liberal democracy. This is done through a fundamental change in human nature and human equality (cf. Fukuyama 2003). Transhumanism is therefore, according to Fukuyama, "the world`s most dangerous idea" (Fukuyama 2004).

If the promises of transhumanism by Artificial Intelligence, i.e. the possibility of the exclusion of death from the reality of human life, in reality turn out to be irredeemable, then this approach would merely displace the irrevocable finiteness of human life (cf. Kamper 1994, p. 20; cf. Kamper 1999, p. 34; cf. Kamper 2000, p. 14 ff.). In this case people would be the deceived ones in the end. The idea of being able to declare death a settled subject would then be a fatal one; it would fail and the transhuman striving for expansion would expose its true face: In the blind striving to make everything technically feasible today and everything technically possible tomorrow actually too, man would threaten to lose himself (cf. Kamper 1995, p. 183): "From the most secret dream of self-deification comes the most uncanny". (Kamper 1995, p. 183, own translation). This "entails a concept of man that advances into a fatal eternity." (Kamper 2001, p. 57, own translation).

That this equation ultimately cannot work out is made clear by Freud's image of the "prosthetic god ..., quite great when he puts on all his auxiliary organs, but they have not grown together with him" (Freud 1948, p. 451, own translation). Anders also unmasks this human striving as a mere wishful dream (cf. Anders 1956, p. 36). And with Kamper one finds, speaking of man as "deus qua machina" (Kamper 1990a, p. 151), in this respect again a content-like résumé: "But the machine that God dreams gets monstrous. With it also the shadows of the other dreams return and devour the symbolic order of language". (Kamper 1996, p. 141; Kamper 2001, p. 40, own translation). And then elsewhere: "Human beings are, after all, like God, but this God is dead.... After all, all human beings are »infiziert « by the distributed power of the infinitely distributed dead God. Everyone has a piece of it. ... But it is precisely this dream that collapses under the weight of its effects." (Kamper 1996, p. 110, own translation). Thus, according to Kamper, man rules in this new world only "if he is dead spirit" (Kamper 1994, p. 54, own translation). If it is not possible to jump off the track, a gloomy prognosis remains in the end from an ethical point of view: "Of course, therefore, one must have the suspicion that there is a mistake in this self-deification and that some kind of fall of man, better said fall of the machines, follows on the feet. (Kamper 1990a, p. 151, own translation). If one considers the meanwhile far advanced research and development in the field of fully autonomous weapon systems for warfare purposes, which in their extreme form do not require any human impetus for action (cf. Sauer 2014), it becomes clear today what such a fall of man, envisaged by Kamper more than 25 years ago, could consist of, at least from an ethical perspective.

\section{Conclusion}

A radical advocacy of Artificial Intelligence for the sake of economic and social progress in the 21st century can neither detach itself from the question of the anthropological premises on which such a commitment is based nor from the ethical consequences. In this context, transhumanism can be identified as a basis of thought. From a psychoanalytical perspective, the motivation for such aworld view respectively concept of man can be interpreted as a combination of defense against fear of death and divine striving for omnipotence. The interpretation of the anthropological foundations of technological singularity also raises the question of the ethical aspects associated with such thinking. This ethical perspective should always be considered as a critical corrective in the discussion about Artificial Intelligence. 


\section{List ofreferences}

Anders, Günther: Die Antiquiertheit des Menschen. Band I: Über die Seele im Zeitalter der zweiten industriellen Revolution, 1956.

Böhme, Gernot: Anthropologie in pragmatischer Hinsicht, 1985.

Freud, Sigmund: Gesammelte Werke, Band XIV: Werke aus den Jahren 1925-1931, 1st edition, 1948.

Fukuyama, Francis: Transhumanism - the world's most dangerous idea, http://www.au.dk/fukuyama/boger/essay/, retrieved 14.7.2019, 2004.

Gehlen, Arnold: Anthropologische Forschung, 1963.

Gehlen, Arnold: Der Mensch, 1974.

Kamper, Dietmar: Hieroglyphen der Zeit. Texte vom Fremdwerden der Welt, 1988.

Kamper, Dietmar: Zwischen Simulation und Negentropie. Das Schicksal des Individuums im Rückblick auf das Ende der Welt, in: Kamper, Dietmar/ Wulf, Christoph (Eds.): Rückblick auf das Ende der Welt, 1990a, pp. 146-154.

Kamper, Dietmar: Gespräch mit Dietmar Kamper vom 6. Juni 1990, http://www.synsign.de/memo/namen/kamperint7.htm as well as the links to the interview content on this page, retrieved 17.7.2019, 1990b.

Kamper, Dietmar: Bildstörungen. Im Orbit des Imaginären, 1994.

Kamper, Dietmar: Unmögliche Gegenwart. Zur Theorie der Phantasie, 1995.

Kamper, Dietmar: Abgang vom Kreuz, 1996.

Kamper, Dietmar: von wegen, 1998.

Kamper, Dietmar: Ästhetik der Abwesenheit, 1999.

Kamper, Dietmar: Bildzwang im Gefängnis der Freiheit, in: Belting, Hans/Kamper, Dietmar (Eds.): Der zweite Blick: Bildgeschichte und Bildreflexion, 2000, pp. 13-21.

Kamper, Dietmar: Horizontwechsel, 2001.

Kurzweil, Raymond: The Singularity is near, 2006.

Lacan, Jacques: Schriften II, 1966.

Lacan, Jacques: Schriften I, 1973.

Lacan, Jacques: Die vier Grundbegriffe der Psychoanalyse. Das Seminar Buch XI, 1987.

Lacan, Jacques: Die Ethik der Psychoanalyse. Das Seminar Buch VII, 1996.

Leroi-Gourhan, Andre: Hand und Wort, 1982.

McCarty, John/Minsky, Marvin/Rochester, Nathan/Shannon, Claude: A proposal for the Darthmouth summer research project on artificial intelligence, http://www-formal.stanford.edu/jmc/history/dartmouth/dartmouth.html, retrieved16.7.2019, 1955.

Morin, Edgar: Das Rätsel des Humanen, 1974.

Plicht, Christine: Künstliche Intelligenz in der Diskussion zwischen Postmoderne und Pragmatismus, https://mathphys.fsk.uni-heidelberg.de/ cplicht/wiss.arbeit_plicht.pdf, retrieved 15.7.2019, 2011.

Sauer, Frank: Autonome Waffensysteme. Humanisierung oder Entmenschlichung des Krieges?,2014.

Tibon-Cornillot, Michel: Die transfigurativen Körper. Zur Verflechtung von Techniken und Mythen, in: Kamper, Dietmar/Wulf, Christoph (Eds.): Die Wiederkehr des Körpers, 1982, pp. 145-164. 